\title{
A NEW SPECIES AND NEW GENUS OF CLAUSILIIDAE (GASTROPODA: STYLOMMATOPHORA) FROM SOUTH-EASTERN HUBEI, CHINA
}

\author{
ZHE-YU CHEN $^{1 *}$, KAI-CHEN OUYANG ${ }^{2}$ \\ ${ }^{1}$ School of Life Sciences, Nanjing University, China (e-mail: chenzheyu1998@163.com); \\ (1) https://orcid.org/0000-0002-4150-8906 \\ ${ }^{2}$ College of Horticulture \& Forestry Science, Huazhong Agricultural University, China \\ *corresponding author
}

\begin{abstract}
A new clausiliid species, in a newly proposed genus, Probosciphaedusa mulini gen. et sp. nov. is described from south-eastern Hubei, China. The new taxon is characterised by having thick and cylindrical apical whorls, a strongly expanded lamella inferior and a lamella subcolumellaris that together form a tubular structure at the base of the peristome, and a dorsal lunella connected to both the upper and the lower palatal plicae. Illustrations of the new species are provided.
\end{abstract}

KEY WORDS: new species, new genus, systematics, Phaedusinae, central China

\section{INTRODUCTION}

In the past decades, quite a few authors have conducted research on the systematics of the Chinese Clausiliidae. Their research hotspots were mostly located in southern China, namely the provinces Sichuan, Chongqing, Guizhou, Yunnan, Guangxi and parts of Guangdong and Hubei, which have a rich malacofauna (GREGO \& SZEKERES 2011, 2017, 2019, 2020, HUNYADI \& SZEKERES 2016, NORDSIECK 2001, 2003, 2005, 2006, 2007, 2012a, 2016). Other regions have been less intensively explored for the Clausiliidae. Recently, the second author and Di Yu conducted a preliminary survey of the hilly area in south-eastern Hubei, which is rarely visited by malacologists or collectors, and collected some terrestrial molluscs. Among them, a clausiliid was identified as a new genus and new species, and its respective descriptions and illustrations are presented herein. Although some molecular phylogenetic studies have focused on the Phaedusinae in East Asia (MоTOCHIN et al. 2017, MAMOs et al. 2021), data on the continental species are still extremely scanty, and because the morphological features of the new genus are sufficiently diagnostic, molecular biology work was not carried out in this study.

\section{MATERIAL AND METHODS}

Photographs were taken using a Canon ${ }^{\circledR}$ 5D Mark IV camera with a Canon ${ }^{\circledR} 100 \mathrm{~mm}$ Macro lens (for overview of shell, genitalia) or Laowa ${ }^{\circledR} 25 \mathrm{~mm}$ Ultra Macro lens (for internal lamellae and palatal plicae), stacked with Zerene Stacker ${ }^{\circledR} 1.04$ and modified in Adobe Photoshop ${ }^{\circledR}$ CS6. Type specimens of the new species are deposited in the Mollusc collection of the
Museum of Hebei University (HBUMM, Baoding, China), Zhe-Yu Chen's private collection (CZYC, Wuhan, China), Kai-Chen Ouyang's private collection (OKCC, Kunming, China), Lu Qiu's private collection (QLC, Luzhou, China), and Yung-Ching Wang's private collection (WYCC, Liaoning, China). 


\section{SYSTEMATIC PART}

\section{Family Clausiliidae Gray, 1855}

Subfamily Phaedusinae A. J. Wagner, 1922

Probosciphaedusa Z.-Y. Chen, gen. nov.

Type species. Probosciphaedusa mulini sp. nov. Diagnosis. Shell slender, with thick and cylindrical apical whorls. Lamella inferior and lamella subcolumellaris strongly expanded, together forming a tubular projection at the base of peristome. Dorsal lunella situated extremely shallow (close to aperture) and connected to both the upper and lower palatal plicae. Etymology. Named for its extreme form of aperture with tubular structure resembling a nose; the Latin word proboscis (proboscis, snout) is combined with the common suffix phaedusa. The name is feminine.

Affinities. The characteristic lamellar structure, the thick, cylindrical apex and the dorsal lunella distinguish the new genus from all the other Phaedusinae. Fuchsiana Gredler, 1887 and Miraphaedusa H. Nordsieck, 2005 share the thick and cylindrical apex with the new genus, but these two genera lack lunella (SCHILEYKO 2000, NORDSIECK 2005, 2012b).
Hemiphaedusa O. Boettger, 1877, Selenophaedusa Lindholm, 1924 and Falsiluna Grego et Szekeres, 2011 are characterised by the presence of a lunella, but none of them shares the extremely shallow situated lunella and the special lamellar structure of the new genus (SCHILEYKO 2000, GREGO \& SZEKERES 2011, NORDSIECK 2012b).

Although the lamellar structure of the new genus shows some similarity with the strongly exposed basal lamellae of Hemiphaedusoides ringens (Schmacker et Boettger, 1890) (YEN 1939), those do not extend beyond the margin of the peristome. A similar fold (originally described as 'keel-like compressed') at the neck of Miraphaedusa also does not distort the shape of the peristome (NORDSIECK 2005). In the Asian Phaedusinae, tubular structure of peristome can be observed in species like Synprosphyma (Excussispira) fargesianella (Heude, 1885) and Zaptyx (Tyrannozaptyx) takarai Kuroda, 1960, but in these species the tubular structure is derived from the sinulus and formed by the lamella superior and principal plica (HEUDE 1885, HABE \& INABA 1996).

Distribution. South-eastern Hubei.

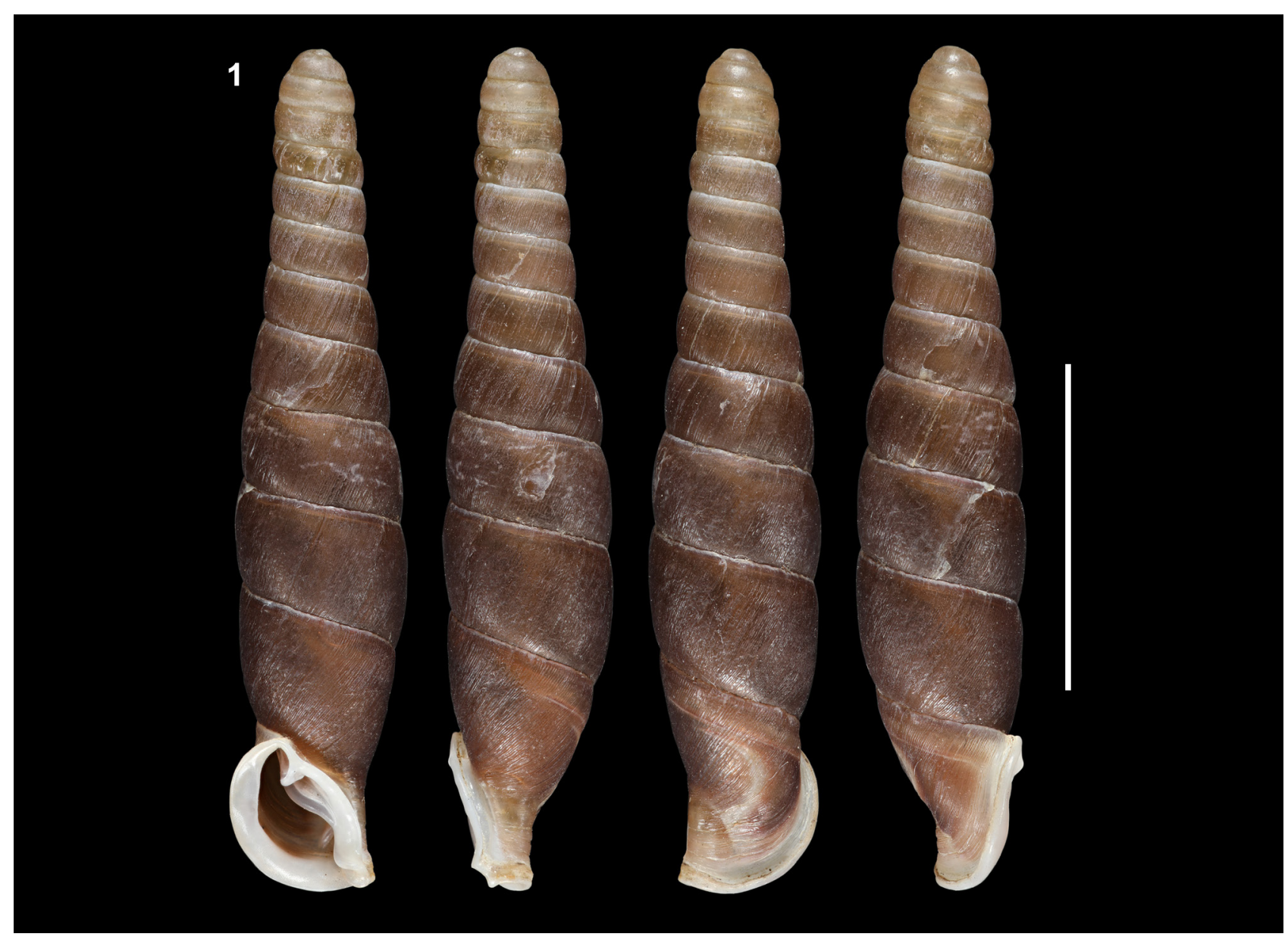

Fig. 1. Shell of Probosciphaedusa mulini Z.-Y. Chen et Ouyang, gen. et sp. nov., holotype HUBMM 10046. Scale bar 10 mm 


\section{Probosciphaedusa mulini Z.-Y. Chen et K.-C. Ouyang, sp. nov.}

(Figs 1-10)

Type material. Holotype, HBUMM 10046 (dry shell with separated soft part in $75 \%$ ethanol), Xuansu Cave (玄素洞), Chibi City (赤壁市), Xianning City (咸宁市), Hubei Province, China, $29^{\circ} 37.85^{\prime} \mathrm{N}, 113^{\circ} 52.17^{\prime} \mathrm{E}$, leg. DI YU, 2020-XI-29. Paratypes: HBUMM 10047 (1 dry shell with dissected soft part in $75 \%$ ethanol), same data as holotype; HBUMM 10048 (15 dry shells), CZYC (one dry shell), OKCC (5 dry shells), WYCC (1 dry shell), QLC (3 dry shells with separated soft parts in $75 \%$ ethanol), south shore of Lushui Lake (陆水湖), Chibi City (赤壁市), Xianning City（咸宁 市), Hubei Province, China, $29^{\circ} 40.20^{\prime} \mathrm{N}, 113^{\circ} 58.58^{\prime} \mathrm{E}$, leg. Di YU \& KAI-CHEN OUYANG, 2020-X-4.

Diagnosis. See diagnosis of the genus.

Description. The medium-sized, sinistral and spindle-shaped shell of 12 whorls is brown or reddish-brown with lighter colour at the thick apical part. The protoconch is comprised of four smooth whorls. The shell is almost cylindrical at the first six whorls, thereafter the outline of the shell becoming somewhat inflated; widest at the penultimate whorl. The entire teleoconch surface is densely and obliquely rib-striated. The base of the neck is enlarged and

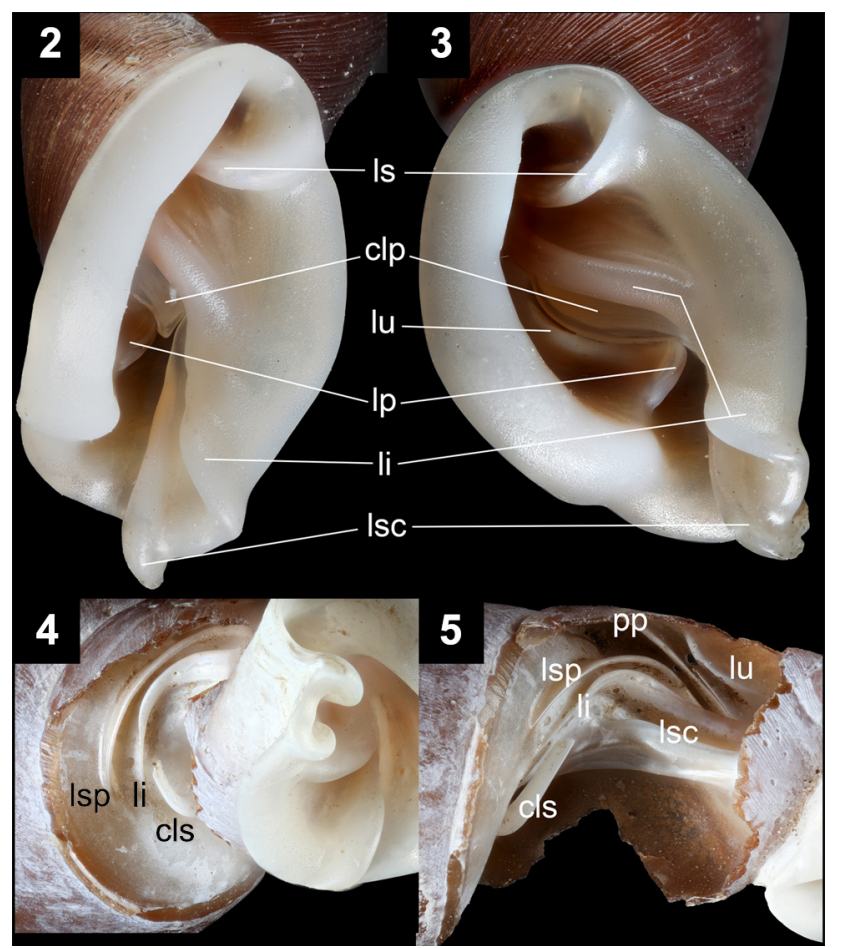

Figs 2-5. Shell characters of Probosciphaedusa mulini Z.-Y. Chen et Ouyang, gen. et sp. nov. Abbrevations: clp clausilium plate; cls - clausilium stalk; li - lamella inferior; lp - lower palatal plica; ls - lamella superior; lsc - lamella subcolumellaris; lsp - lamella spiralis; lu lunella; pp - principal plica folded backwards, forming a tubular structure. This conspicuously extended lobe is formed by the terminal parts of the lamella inferior and the lamella subcolumellaris. The oval aperture joins a detached peristome and has a wide and strongly reflexed white margin. The lamella inferior starts laterally, at the same depth as the lamella spiralis. It reaches the peristome at mid-height of the aperture, then bends downward and extends far beyond the curve of the aperture. The lamella subcolumellaris descends along a straight line and reaches downward farther than the lamella inferior, with which it forms the extended tubular structure. The strong, oblique lamella superior is continuous with the lamella spiralis. The lunella is situated at the dorsal side, extremely close to aperture margin. The principal plica starts dorsolaterally and extends almost to the peristome. The long, dorsal upper palatal plica runs almost parallel to the principal plica. Its front end is fused to the arched lunella, which is also connected to the central part of the long lower palatal plica, which is almost parallel to the lamella subcolumellaris. The anterior part of the lower palatal plica (basalis) is well visible in apertural view. The clausilium plate with a pointed tip is partly visible through the aperture. Its distal end is inserted into the groove formed by the lower palatal plica and the lamella subcolumellaris. The body is brown with an orange hue. The foot margin is greyish-white. Skin patches are dark brown.

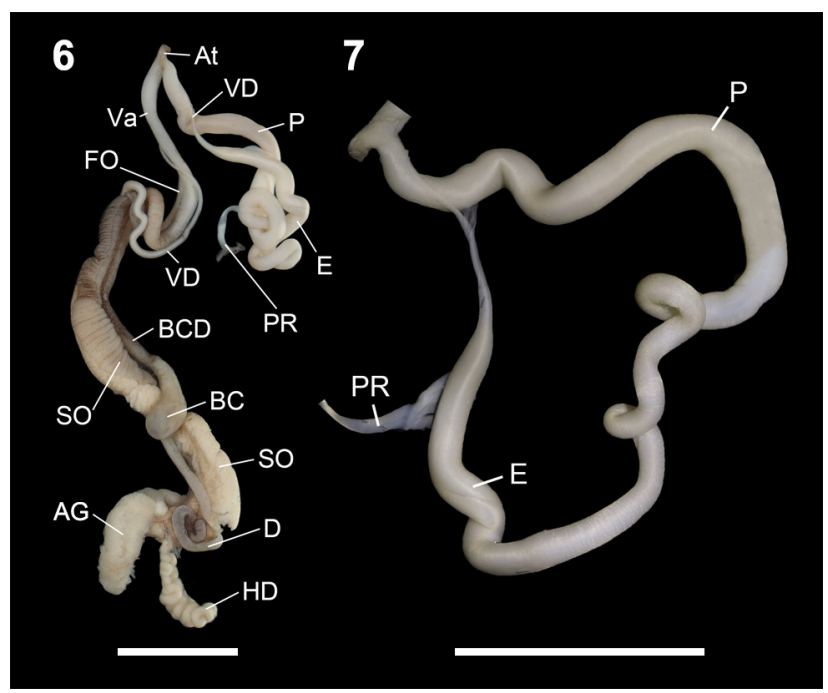

Figs 6-7. Genital anatomy of Probosciphaedusa mulini Z.-Y. Chen et Ouyang, gen. et sp. nov.: 6 - general view; 7 male part. Scale bars $5 \mathrm{~mm}$. Abbrevations: AG - albumen gland; At - atrium; BC - receptacle of bursa copulatrix; BCD - bursa copulatrix duct; D - diverticulum of bursa copulatrix; E - epiphallus; FO - free oviduct; HD - hermaphroditic duct; SO - spermoviduct; P - penis; PR - penial retractor muscle; VA - vagina; VD - vas deferens 


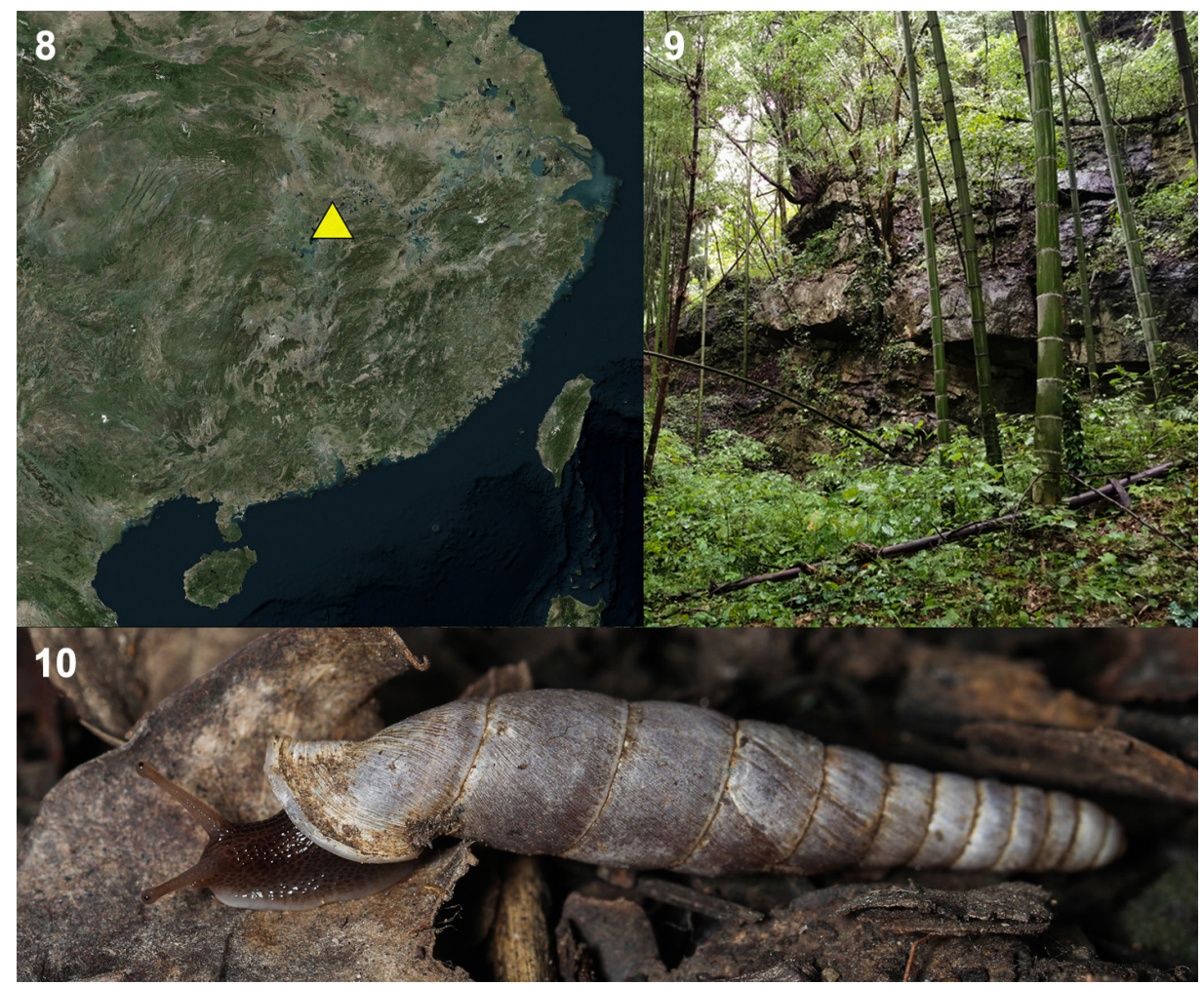

Figs 8-10. Probosciphaedusa mulini Z.-Y. Chen et Ouyang, gen. et sp. nov.: 8 - satellite image of southern China indicating the geographic position of the type locality of $P$. mulini (yellow triangle); 9 - habitat of $P$. mulini; 10 - live specimen of P. mulini, paratype HBUMM 10047

Measurements (in mm). Shell height 23.74-30.00, shell width 4.50-5.68, aperture height 4.37-5.77, aperture width 3.82-4.71 $(\mathrm{n}=18)$.

Etymology. Named after its collector Di Yu's son, Mu-Lin Yu.

Remarks on the genitalia. Paratype HBUMM 10047 was dissected to examine the structure of the genitalia. The result is as follows: penis long, folded near the atrium. No clear boundary between penis and epiphallus. The penis-epiphallus part is long, coiled, and has obviously thickened muscular inner wall. The penial retractor muscle is attached at the transition between epiphallus and vas deferens. The vas deferens is distinctly thickened in the female part, muscular, and thickest close to the spermoviduct. Spermoviduct is long. The bursa copulatrix duct is relatively short, ca. $5 \mathrm{~mm}$, accounting for only half of the length of the spermoviduct. The receptacle of bursa copulatrix is ovoid, separated from spermoviduct. The diverticulum of bursa copulatrix much longer than the bursa copulatrix duct, ca. $14 \mathrm{~mm}$, its end is coiled and uninflated, and attached by connective tissue to the spermoviduct. The albumen gland is relatively small compared to the spermoviduct. The hermaphroditic duct is nearly as long as the albumen gland.

Distribution. This species is known only from a limited area in south-eastern Hubei.

\section{ACKNOWLEDGEMENTS}

Thanks go to Mr. DI YU [余迪] for the support of the field work and to Prof. MikLós SzekERES for his critical help with the draft version of this article. Thanks are also due to four anonymous reviewers for their helpful comments.

\section{REFERENCES}

BOETTGER O. 1877. Clausilienstudien. Verlag von Theodor Fischer, Cassel.

https://doi.org/10.5962/bhl.title.11463

Gredler V. 1887. Zur Conchylien-Fauna von China. X. Stück. Malakozoologische Blätter 9: 121-163.
Grego J., SzeKERES M. 2011. New taxa of Asiatic Clausiliidae (Mollusca: Gastropoda). Visaya 3: 4-22.

GREgo J., SZEKERES M. 2017. New Clausiliidae (Mollusca: Gastropoda) from China. Visaya 4: 79-93.

Grego J., SZEKERES M. 2019. Two new species of Clausiliidae (Gastropoda: Pulmonata) from Yunnan 
Province, Southern China. Folia Malacologica 27: 315320. https://doi.org/10.12657/folmal.027.029

GREGO J., SZEKERES M. 2020. Six new species of Clausiliidae (Mollusca: Gastropoda) from Southern China. Visaya 5: 51-59.

HABE T., INABA A. (eds) 1996. Catalogue of the shellfish type specimens described by the late Dr. Tokubei Kuroda in the possession of Nishinomiya City. Nishinomiya City, Hyogo.

HEUDE R. P. M. 1885. Mémoires concernant l'histoire naturelle de l'empire chinois par des pères de la Compagnie de Jésus. Notes sur les Mollusques terrestres de la vallée du Fleuve Bleu. III: 89-132.

HuNYADI A., SZEKERES M. 2016. New taxa and distribution data of Clausiliidae (Gastropoda: Pulmonata) from southeastern China. Journal of Conchology 43: 129150.

KuRODA T. 1960. Okinawa guntosan kairui mokuroku (tosokurui o nozoku). A catalogue of the molluscan fauna of the Okinawa Islands (exclusive of the Cephalopoda). Ryukyu University Kyomubu Fukyuka, Okinawa, NahaShi.

LINDHOLM W. A. 1924. A revised systematic list of the genera of the Clausiliidae, recent and fossil, with their subdivisions, synonymy, and types. Proceedings of the Malacological Society of London 16: 53-64. https://doi.org/10.1093/oxfordjournals.mollus.a063835

Mamos T., UIT DE WeERD D., VON OHeImb P. V., SULIKOWSKA-DROZD A. 2021. Evolution of reproductive strategies in the species-rich land snail subfamily Phaedusinae (Stylommatophora: Clausiliidae). Molecular Phylogenetic and Evolution 158: 107060. https://doi.org/10.1016/j.ympev.2020.107060

Motochin R., WANG M., Ueshima R. 2017. Molecular phylogeny, frequent parallel evolution and new system of Japanese clausiliid land snails (Gastropoda: Stylommatophora). Zoological Journal of the Linnean Society 181: 795-845. https://doi.org/10.1093/zoolinnean/zlx023

NORDSIECK H. 2001. Revision of the system of the Phaedusinae from mainland China (Gastropoda: Stylommatophora: Clausiliidae), with the description of new taxa. Archiv für Molluskenkunde 129: 25-63. https://doi.org/10.1127/arch.moll/129/2001/25

NORDSIECK H. 2003. Systematic and nomenclatural notes on Phaedusinae with the description of new taxa (Gastropoda: Stylommatophora: Clausiliidae). Archiv für Molluskenkunde 132: 121-141. https://doi.org/10.1127/arch.moll/132/2003/121
NORDSIECK H. 2005. New taxa of Phaedusinae and Garnieriinae from mainland China and Taiwan (Gastropoda: Stylommatophora: Clausiliidae). Archiv für Molluskenkunde 134: 23-52.

https://doi.org/10.1127/arch.moll/0003-9284/134/023-052

NORDSIECK H. 2006. Clausiliidae of China - a survey on a fascinating group of land snails (Gastropoda, Stylommatophora, Clausiliidae). Club Conchylia Informationen 38: 12-21.

NORDSIECK H. 2007. New taxa of Phaedusinae and Garnieriinae from southern China. Archiv für Molluskenkunde 136: 217-243.

https://doi.org/10.1127/arch.moll/0003-9284/136/217-243

NORDSIECK H. 2012a. Clausiliidae of Guangxi, southern China (Gastropoda, Pulmonata, Stylommatophora). Acta Conchyliorum 12: 3-56.

NORDSIECK H. 2012b. Check-list of the Clausiliidae of mainland China (Gastropoda, Stylommatophora). Acta Conchyliorum 12: 63-73.

NordsiecK H. 2016. New species taxa of Clausiliidae (Gastropoda, Stylommatophora) from China and Vietnam. Conchylia 47: 37-57.

PfEIFFER L., GRAY J. E. 1855. Catalogue of Pulmonata or air-breathing Mollusca in the collection of the British Museum, Part I. Taylor \& Francis, London.

SCHILEYKO A. A. 2000. Treatise on recent terrestrial pulmonate molluscs, Part 5, Clausiliidae. Ruthenica, Supplement 2: 565-729.

SCHMACKER B., BOETTGER O. 1890. Neue Materialien zur Charakteristik und geographischen Verbreitung chinesischer und japanischer Binnenmollusken I. Nachrichtsblatt der Deutschen Malakozoologischen Gesellschaft 22: 1-30, 113-137.

WAGNER A. J. 1922. Uzupełnienia i przyczynki do systematyki Clausiliidów. Ergänzungen und Erläuterungen zur Systematik der Clausiliiden. Annales Zoologici Musei Polonici 1: 96-111.

YEN T.-C. 1939. Die chinesischen Land- und SüßwasserGastropoden des Natur-Museums Senckenberg. Abhandlungen der Senckenbergischen Naturforschenden Gesellschaft 444: 1-234, 16 pls.

Received: January 13th, 2021

Revised: February 26th/March 3rd, 2021

Accepted: March 8th, 2021

Published on-line: March 19th, 2021 